\title{
The Effect of Profitability, Foreign Activity, and Hedging on Tax Avoidance with Executive Character as Moderating Variables
}

\author{
Puteri Cinta Annisa Siregar ${ }^{1}$, Gita Darin Kurnia Saputri², IGB Nowindra ${ }^{3}$, \\ Afifah Farhanah ${ }^{4}$, Deni Darmawati ${ }^{5}$ \\ \{pcintasiregar@gmail.com ${ }^{1}$, gita.darin@gmail.com ${ }^{2}$, owinnowindra@gmail.com³ \\ afifahfarhanah3005@gmail.com ${ }^{4}$,deni_darmawati@trisakti.ac.id ${ }^{5}$ \} \\ Universitas Trisakti ${ }^{1,2,3,4,5}$
}

\begin{abstract}
This quantitative study determined the effect of profitability, foreign activity, and hedging on tax avoidance with executive characteristics as a moderating variable. Samples were 16 multinational companies listed on the Indonesia Stock Exchange from 2017 to 2019 with hedging transactions. They were chosen purposively and observed for three years, so the study had 48 samples in total. Data were analyzed using multiple regression analysis. The results showed that profitability negatively affected tax avoidance, foreign activity positively affected tax avoidance, and hedging positively affected tax avoidance. Findings confirmed that executives with a risk-taker characteristic could weaken the negative effect of profitability on tax avoidance and weaken the positive influence of foreign activity on tax avoidance. It indicated that executives with a risk-taker characteristic might conduct tax avoidance practices in companies with high foreign transaction activities. Executives with a risktaker characteristic had no influence on the relationship between hedging and tax avoidance.
\end{abstract}

Keywords: Profitability; Foreign Activity; Hedging; Tax Avoidance; Executive Characteristics

\section{Introduction}

Tax is a mandatory contribution to the state that is owed by an individual or entity that is coercive in nature based on the law, with no direct compensation and is used for the needs of the state for the greatest prosperity of the people. Based on data obtained from the Central Statistics Agency, state revenue in 2021 is in the form of taxes by $82.45 \%$ and the rest is nontax revenues and grants. This means that the majority of state revenues or revenues come from taxes. Taxes as a source of state revenue will provide benefits to be used to finance state expenditures (budgetair function), namely as a driving force for the wheels of government and financing the implementation of national development and supporting economic activities as well as a tool to regulate or implement government policies in the social and economic fields, through providers of facilities. public (regulatory function). However, society and 
organizations consider taxes to be a burden because they reduce income and do not bring direct benefits and the main goal of society and organizations in general is profit maximization.

For companies, taxes are costs that can reduce net income. The greater the profit of a company, the greater the tax to be paid [1]. It is makes many companies look for ways to reduce the amount of tax payments, both legal and illegal, one of which is tax avoidance. Tax avoidance is one way to avoid taxes without violating the rules of taxation. One of the cases of tax evasion in Indonesia is the case of PT Toyota, which is a company that is still a subsidiary of the ASTRA company which is incorporated in ISSI (Indonesian Sharia Stock Index). The Directorate General of Taxes accused PT Toyota Motor Manufacturing Indonesia of avoiding paying taxes worth $\mathrm{Rp} 1.22$ trillion by means of transfer pricing. This research uses agency theory, which is a theory that arises because of a conflict of interest between the principal and the agent.

In the international world, there are three giant technology companies, namely Google, Facebook and Microsoft that practice tax avoidance in several countries with high tax rates where the three companies operate, one of which is Indonesia. These big companies take advantage of loopholes in the global taxation system in order to avoid taxes. Its value reaches USD 2.8 billion or equivalent to $\mathrm{Rp} 41$ trillion per year. The three companies made huge profits during the pandemic but they contributed little to public services in several countries. From this case, the practice of tax avoidance can worsen the company's image because it is considered a bad action even though it is not a violation of the law. However, many company managements continue to practice this tax avoidance. Based on the literature review and previous research, the authors try to connect and test the significant influence between executive character, profitability, foreign activity, and hedging on tax avoidance.

Profitability is a measuring tool in assessing a company's capability in creating profits in utilizing its assets or what is termed Return On Assets (ROA). According to the results of research conducted by Salman \& Juniarti, it is concluded that the profitability variable cannot significantly affect tax avoidance, where the proxy used for profitability is Return On Assets. More than 5 (five) official journals related to profitability and tax avoidance are only affected by ROA, measuring profitability is Return On Assets (ROA) to assess the efficiency of capital use in organizations or companies [2].

In the case of Google, Facebook and Microsoft, it shows that these companies practice tax avoidance with a foreign activity strategy. Companies that do tax avoidance are usually multinational companies (MNCs) that take advantage of differences in tax rates by placing their operations in countries that have lower income tax rates so that they have a low income tax burden [3]. The previous research related to foreign activity was conducted by Zamani [3]. shows that showing foreign activity has no effect on tax avoidance, this is because foreign activity is not the main factor underlying companies to practice tax avoidance because not all companies have subsidiaries abroad. Previous research in Indonesia related to foreign activity was conducted by Dewi \& Jati who found that foreign activity had no effect on tax avoidance in manufacturing companies during 2009-2012 [4]. However, different results are shown in research Afriani et al., which shows that foreign activity has a significant positive effect on tax avoidance because it is factored in by differences in tax rates in each country and is one of the effective ways for companies to practice tax avoidance. in line with research Ferdiawan \& Firmansyah, which shows that foreign activity has a significant positive effect on Tax Avoidance [5], [6]. So, the conclusion from previous researchers is that foreign activity has a significant positive effect on tax avoidance due to the opportunity to do tax avoidance by 
taking advantage of loopholes in tax regulations that are considered safe for companies in each country by diverting sales to countries with low tax rates.

According to Andika and Sari [7] Hedging is a transaction used to reduce risk. According to Madura [8]. Hedging is a contract that aims to protect exposure to exchange rates. In general, hedging is a risk management action to reduce or even avoid possible losses caused by exchange rates, interest rates, stock prices or commodities. Hedging is almost similar to insurance, where when one party suffers a loss due to a certain risk, that party will receive compensation from the other party who has agreed to the contract. Hedging practice is one of the strategies to reduce the possibility of unexpected business risks arising.

An executive is someone whose position is very important in a company. In the hands of the executive, all operational activities and the running of the company are handled. The executive is in charge of coordinating the running of a company. Organizations are led by a hierarchy of managers, with the chief executive officer (CEO) at the top, where these leaders have diverse qualities and styles of decision-making. The leader can be someone who is not afraid of risk, or someone who is afraid of risk. In addition, according to Lewellen"Executive character shows how the actions taken by company leaders when faced with a risk [9]. The decisions taken will describe whether the executive is a person who dares to take risks or not. From this explanation, if you pay attention, the decisions taken by executives for the running of the company are influenced by the character of each individual.

Based on the background described above, the researcher wants to conduct a research entitled "The Effect of Profitability, Foreign Activity, and Hedging on Tax Avoidance with Executive Characters as Moderating Variables"

\subsection{Formulation of the Problems}

1. Is there any influence of profitability on tax avoidance?

2. Is there any influence of foreign activity on tax avoidance?

3. Is there any effect of hedging on tax avoidance?

4. Is there an effect of profitability with the executive character as moderating?

5. Is there any influence of foreign activity on tax avoidance with the executive character as moderating?

6. Is there any effect of hedging on tax avoidance with the executive character as moderating?

\subsection{Research purposes}

1. To analyze the effect of executive profitability on tax avoidance.

2. To analyze the effect of foreign activity on tax avoidance.

3. To analyze the effect of hedging on tax avoidance.

4. To analyze the effect of executive profitability on tax avoidance with the executive character as moderating.

5. To analyze the effect of executive foreign activity on tax avoidance with the presence of an executive character as moderating.

6. To analyze the effect of executive hedging on tax avoidance with the executive character as moderating. 


\subsection{Benefits of research}

a) For Literature

The results of this research are expected to be useful for the development of science and increase the reader's insight regarding the relationship and influence of profitability, foreign activity, and hedging on tax avoidance moderated by executive character.

b) For Investors

The results of this research are expected to provide benefits for investors in making decisions to invest based on the considerations of executive character, profitability, foreign activity, and hedging in an effort to minimize tax avoidance thereby reducing investment risk.

c) For Policy Makers (Regulators)

The results of this research are expected to provide benefits for related institutions in terms of regulation and enforcement of the effectiveness of tax avoidance from the executive character, profitability, foreign activity, and hedging so that state revenues will increase from tax collection.

\section{Review of Related Literature and Hypothesis Development}

\subsection{Literature Review}

\section{a) Profitability}

According to Sartono the definition of profitability ratios is the company's ability to earn profits in relation to sales, total assets, and own capital [10]. Profitability is an important component that potential investors and shareholders pay attention to to see the company's efficiency based on the profits earned. Profitability consists of several types of ratios that can be used to assess and measure the company's financial position in a certain period. The types of profitability ratios are as follows:

1) Gross Profit Margin (GPM)

This ratio is used to measure the ability of the company's gross profit level.

2) Net Profit Margin (NPM)

This ratio is used to measure the level of effectiveness of the company in carrying out its operations.

3) Return On Assets (ROA)

This ratio is used to show the company's success in generating profits.

4) Return on Equity (ROE)

This ratio is used to measure the company's investment return, both from own capital and shareholders.

5) Operating Profit Margin (OPM)

This ratio is used to measure the level of net profit after cost of goods sold and operating costs.

6) Earnings Per Share (EPS)

This ratio is used to measure the level of success of management in achieving profits for shareholders.

7) Gross Profit Margin (GPM)

This ratio is used to measure the ability of the company's gross profit level. 
8) Net Profit Margin (NPM)

This ratio is used to measure the level of effectiveness of the company in carrying out its operations.

9) Return On Assets (ROA)

This ratio is used to show the company's success in generating profits.

10) Return on Equity (ROE)

This ratio is used to measure the company's investment return, both from own capital and shareholders.

11) Operating Profit Margin (OPM)

This ratio is used to measure the level of net profit after cost of goods sold and operating costs.

12) Earnings Per Share (EPS)

This ratio is used to measure the level of success of management in achieving profits for shareholders.

Andhari \& Sukartha, uses ROA as a proxy for profitability and states that profitability has a positive effect on tax avoidance. So the authors decided to use this ratio, namely Return On Assets (ROA) as a measuring tool in research and the basis for analyzing tax avoidance practices in companies [11].

\section{b) Foreign Activity}

It is known by researchers in developed countries that foreign activities carried out by multinational companies tend to report lower taxable income than companies that do not have foreign activities in their business. Multinational companies have the opportunity to transfer income to other companies that are affiliates or the term is called income shifting. Usually the affiliate company is located in the country that has the lowest income tax rate in order to avoid tax rates that are too large. The U.S. multinationals implement various strategies to lower taxes. According to Rego companies that have foreign activities have the opportunity to reduce income tax by doing income shifting to countries that have low tax rates [12]. The variation of ETR in Australia had a significant negative sign. That it is evidence that companies may use their foreign activity to reduce tax payments in their country . Especially in ASEAN, the tax rate in Indonesia (25\%) can be said to be quite high compared to Singapore $(17 \%)$, Thailand (20\%), and even Vietnam (22\%).

\section{c) Hedging}

Hedging is a strategy to reduce the emergence of unexpected business risks. According to Subramanyam \& Wild Hedging is an agreement made between one party and another with the aim of protecting the company from market risk [13]. This hedging practice is expected to protect the company from possible losses caused by changes in interest rates. exchange rates, and changes in the prices of major commodities.

\section{d) Executive Character}

Executive character is very influential for the survival or sustainability of a company. According to Low the chief executive of a company has two characters, the first is a risk taker and the second is a risk averse [14]. Risk taker is a type of executive character who dares to take risks, while risk averse is a type of executive character who tends to be less daring in 
taking risks. For example, in this case, usually executives with risk taker characters dare to do everything to gain profits for the company, while risk averse is the opposite.

\section{e) Tax Avoidance}

According to Palan, a transaction is indicated as tax avoidance if it takes one of the following actions [15]:

1. Taxpayers (WP) try to pay less tax than they should owe by taking advantage of the fairness of interpretation of tax law.

2. Taxpayers (WP) try to have tax imposed on declared profits and not on profits that are actually earned.

3. Taxpayers (WP) seek to postpone tax payments.

In contrast to several previous studies described by (Dewi \& Jati, 2014) using Cash ETR (Effective Tax Rate) as a measurement of tax avoidance. The measurement of tax avoidance in this research adopts research from Guenther, which uses Book Tax Difference (BTD) because it is considered that Cash ETR only reflects non-aggressive tax avoidance, while BTD reveals a more aggressive side of tax avoidance [16].

\subsection{Research Framework}

Based on the background, problem formulation, and literature review that has been described, the researcher formulates a research framework to facilitate research. The following Figure 1 describes the research framework.

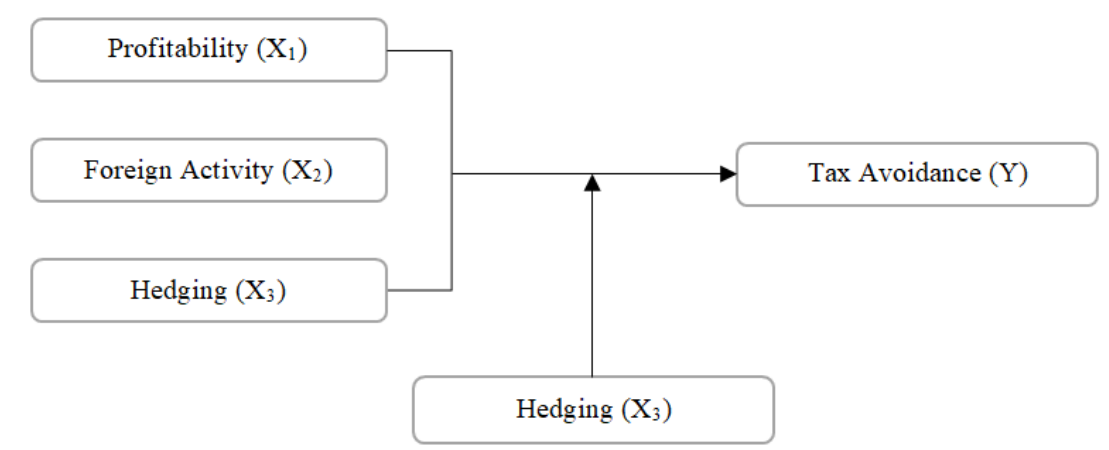

Fig. 1. Research Framework

\subsection{Hypothesis Development}

\section{a) Profitabilitiy and Tax Avoidance}

The value of the company's profitability affects its tax payment obligations, with increasing profitability, the tax value also increases, and vice versa. There are five types of financial ratio analysis and profitability is one of them [17]. The profitability ratio is considered effective to be the main measuring tool in determining the good or bad performance of the company based on its financial statements. Of the many formulas used to measure profitability ratios, the authors choose to use Return On Equity (ROE). The results of 
the research Andhari \& Sukartha, state that there is a positive relationship between profitability and tax avoidance where the larger the company generates profits, the more likely it is that the company uses tax avoidance practices in reducing the value of its tax obligations [11]. It can be concluded that companies that have a high level of profit tend to use their resources efficiently so that they can reduce tax payments. Based on previous research, the first hypothesis on the relationship between profitability and tax avoidance can be formulated as:

$\mathrm{H}_{1}=$ Profitability has a positive effect on tax avoidance.

\section{b) Foreign Activity dan Tax Avoidance Foreign Activity and Tax Avoidance}

The research conducted Afriani et al., has a significant positive effect on tax avoidance using data from all companies listed on the IDX [5]. Research conducted Ferdiawan \& Firmansyah, shows results that support the results of research Afriani et al., where the Foreign Activity variable has an effect on Tax Avoidance [5], [6]. Companies that have a wide business network to overseas will automatically have a lot of income and the multinational company must follow the regulations in accordance with the income tax rates that apply in the place where the company operates. This relatively large income will have an impact on the income tax burden that must be paid. This will make the management strive to minimize taxes by utilizing overseas subsidiaries operating in countries with lower tax rates than Indonesia. This action is legal because the company does not manipulate company information but only transfers some of its income to subsidiaries. This picture gives an indication that it is possible for companies to take advantage of foreign activity to reduce tax payments in Indonesia. Thus, the second hypothesis for this research, is:

$H_{2}=$ foreign activity has a positive effect on tax avoidance.

\section{c) Hedging and Tax Avoidance}

Differences in desire between the management of a company and investors will cause the emergence of different information when disclosing financial statements. The management of the company who has the authority to prepare reports has more information than investors which will ultimately be used by management to avoid tax through hedging transactions. Donohoe \& Robert Knechel, used tax aggressiveness proxies with effective tax rates and cash ETR to examine the effect of hedging on tax aggressiveness [18]. The results of this research prove that derivatives have a significant effect on tax aggressiveness. Oktavia \& Martani also proves that users of financial derivatives have a positive effect on tax avoidance [19]. Based on previous research, it can be stated that the fourth hypothesis in this research is:

$\mathrm{H}_{3}=$ Hedging has a positive effect on tax avoidance.

\section{d) Executive Characteristics as Moderating Variable between Profitability and Tax Avoidance}

In research by Maharani \& Suardana, it is stated that companies that earn profits are assumed not to do tax avoidance because they are able to regulate their income and tax payments [20]. Meanwhile, research by Andhari \& Sukartha, states that there is a positive relationship between profitability and tax avoidance where the larger the company generates profits, the more likely it is that the company uses tax avoidance practices in reducing the value of its tax obligations [11]. If you pay attention, both of these things can happen or be 
avoided depending on how company executives will make decisions. If the company executive has a risk taker character, it is likely that tax evasion will be carried out. Based on this description, the following hypotheses can be formulated:

$\mathrm{H}_{4}=$ Executive characteristics moderate the effect of profitability on tax avoidance.

\section{e) Executive Characteristics as Moderating Variable between Foreign Activity and Tax Avoidance}

Foreign activities carried out by multinational companies (MNCs) certainly operate in different countries with different income tax rates. The difference in income tax rates in various countries creates a gap that is used by companies that have foreign activities to avoid taxes, even though tax evasion is legal by attaching real financial information. However, every foreign activity in the business of multinational companies is certainly influenced by the company's decisions and policies taken by the leader of the company. The more foreign activity is carried out, the more the company's financial policies will be interfered with by the company's leaders because it involves affiliated companies located in other countries. Therefore, the character of executives in companies that carry out foreign activities can influence policies to carry out tax avoidance in accordance with research conducted Ferdiawan \& Firmansyah, showing results that support the results of research Afriani et al., which is the Foreign Activity variable effect on Tax Avoidance [5], [6]. Based on this description, the sixth hypothesis can be formulated as follows::

$\mathrm{H}_{5}=$ Executive characteristics moderate the effect of foreign activity on tax avoidance.

\section{f) Executive Characteristics as Moderating Variable between Hedging and Tax Avoidance}

Not a few companies use hedging to cover up or hide the company's operations from investors. So that investors do not care about the opportunistic actions of a company, including tax avoidance. According to Ramadhani et al., if used in a good manner, hedging will keep the company's sales or financing within tolerable risks. In this case, the company's stakeholders, especially executives, play a very large role in determining what kind of hedging will be used [21]. Therefore, it is possible that the executive character can affect the relationship between hedging and tax avoidance. Based on this description, the sixth hypothesis can be formulated as follows:

$\mathrm{H}_{6}=$ Executive characteristics moderate the effect of hedging on tax avoidance.

\section{Research Methods}

\subsection{Research Design}

This article is a type of causal research with the organization as the unit of analysis. The object in this research involves data from manufacturing companies listed on the Indonesia Stock Exchange from 2017 to 2019 so that the time horizon for this research is included in the data pool. This type of research is associative research, namely research that aims to analyze the relationship between a variable and other variables (Sugiyono \& Kuantitatif, 2009). 


\subsection{Variables and Measurements}

This research consists of 3 (three) variables, namely the dependent variable, independent variable and moderating variable. The dependent variable used in this research is tax avoidance (Y). The measurement of tax avoidance in this research uses the Book Tax Difference calculation. Calculation of Book Tax Difference as the difference between taxable income and net income with a scale of total assets (Purwantini, 2017). Book tax difference categorizes companies currently undertaking tax avoidance efforts with a score of more than or equal to 0.076 (BTD 0.076). Meanwhile, the value of BTD which is categorized as not currently undertaking tax avoidance efforts is less than 0.076 (BTD < 0.076) (Purwantini, 2017). The researcher used formula (1):

Book Tax Difference $=\frac{\text { Profit Before Tax-Profit After Tax }}{\text { Average Asset }}$

The independent variables related to the research are profitability $\left(\mathrm{X}_{1}\right)$, foreign activity $\left(\mathrm{X}_{2}\right)$, and hedging $\left(\mathrm{X}_{3}\right)$. Profitability $\left(\mathrm{X}_{1}\right)$ is a measurement of the company's financial performance. The level of tax paid by the company is influenced by the profit generated during the current period. (Aulia, 2021) uses ROA as a proxy for research with the assumption that the company makes tax deductions by utilizing depreciation and amortization expenses. Formula (2) calculates Return on assets (ROA):

Return On Assets $=\frac{\text { Earning Before Tax }}{\text { Total Assets }}$

Foreign Activity $\left(\mathrm{X}_{2}\right)$ is represented by a multinational company (MNC) as a company located in two or more countries which reflects the organizational form of foreign investment. To measure foreign activity in his book, Kennely (2016) reveals several proxies, including: This research will use the measurement using the proxy used by Rasmawarmy (1992) by comparing total foreign sales with total global sales. Formula (3) measures Foreign Activity by proxy:

Foreign Activity $=\frac{\text { Total Foreign Sales }}{\text { Total Global Sales }}$

Hedging $\left(\mathrm{X}_{3}\right)$ is measured using a proxy used (Donohoe \& Robert Knechel, 2014) in measuring financial derivatives with the formula (4):

FVHED $=\frac{\text { Absolute value of } f v \text { of hedge }}{\text { Total asset } t-1}$

The moderating variable related to this research is the executive character $(Z)$ measured by corporate risk-taking by calculating the standard deviation of EBITDA. If the risk value obtained is high, then the type of executive character is a risk taker. Meanwhile, if the resulting risk value is low, then the type of executive character is risk averse. So the company executives in this research were measured by the formula (5):

Risk $\left.=\sqrt{\sum_{T-1}^{T} \quad\left(E-\frac{1}{T}\right.} \sum_{T-1}^{T} \quad E\right) 1 /(T-1)$ 


\subsection{Sampling method}

The population in this research are manufacturing companies listed on the Indonesia Stock Exchange in 2017-2019. The sampling method used in this research is non-probability sampling with purposive sampling technique, namely the sampling method with predetermined criteria and carried out in accordance with certain objectives [22]. The research samples included in this research are manufacturing companies that meet the criteria. The sample selection criteria used in this research are as follows:

a. Manufacturing companies listed on the Indonesia Stock Exchange from 2017 to 2019

b. The listed company publishes financial statements ending December 31;

c. The listed company uses the rupiah currency in reporting

d. The listed companies have complete financial data to calculate the variables in this research such as (RISK, ROA, ROE, FA, and FVHED) that are relevant during the observation period, namely 2017 to 2019.

\subsection{Data Collection}

Sources of data used in this research is secondary data. According to Sugiyono secondary data sources are sources that do not directly provide data to data collectors, for example through other people or documents [22]. Secondary data in this research were obtained through financial reports that have been published through http://www.idx.co.id/ and have a relationship with the topic of the problem being reasearched.

\subsection{Data Analysis}

The data analysis technique used in this research is multiple regression analysis to examine the effect of Profitability $\left(\mathrm{X}_{1}\right)$, Foreign Activity $\left(\mathrm{X}_{2}\right)$, and Hedging $\left(\mathrm{X}_{3}\right)$ on Tax Avoidance $(\mathrm{Y})$ in the presence of Executive Character $(\mathrm{Z})$ as moderating. The mathematical model in this research is presented in formula (6):

$$
Y=\alpha+\beta_{1} X_{1}+\beta_{2} X_{2}+\beta_{3} X_{3}+\beta_{4} X_{1} X_{4}+\beta_{5} X_{2} X_{4}+\beta_{6} X_{3} X_{4}+€
$$

Description :

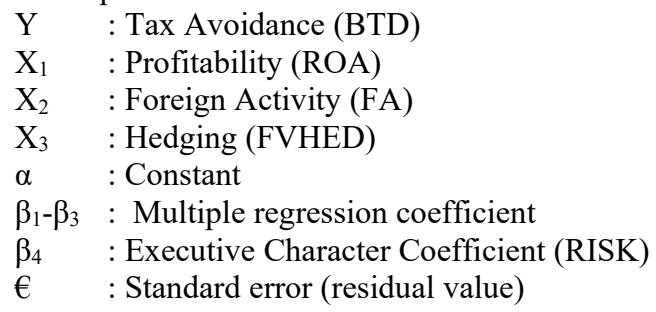

\section{Research Findings and Discussion}

The population in this research were 486 multinational companies listed on the Indonesia Stock Exchange which were taken directly on the website www.idx.co.id in $2017-2019$ and the websites of related companies. The sampling technique used is purposive sampling. Table 
1 presents the sample selection.

Table 1. Sample Selection Result Data

\begin{tabular}{clc}
\hline No & \multicolumn{1}{c}{ Description } & Total \\
\hline 1 & Companies listed on the IDX in 2017 - 2019 & 486 \\
2 & Companies that do not declare foreign activities in the annual report & $(285)$ \\
3 & Companies that do not have complete data for variable calculations & $(147)$ \\
4 & The number of companies that are eligible to be used as research samples & 54 \\
5 & Number of companies sampled for 3 years (2017-2019) & 48 \\
& Total final research sample & 48 \\
\hline
\end{tabular}

\subsection{Descriptive Statistics Test Results}

Descriptive statistical data analysis presented in this research includes Minimum, Maximum, Mean, and Standard Deviation (SD). The following Table 2 presents the results of descriptive statistical analysis of research data:

Table 2. Descriptive Statistics

\begin{tabular}{lccccc}
\hline & N & Minimum & Maximum & Mean & Std. Deviation \\
\hline BTD & 48 & 0.00095 & 0.20125 & 0.028817 & 0.0298742 \\
ROE & 48 & 0.00040 & 2.69000 & 0.141304 & 0.3905768 \\
FA & 48 & 0.00580 & 0.93955 & 0.314835 & 0.2836875 \\
& & & & & \\
FVHED & 48 & 0.00000 & -0.05391 & -0.004563 & 0.0103585 \\
RROA & 48 & 0.00005 & 0.41157 & 0.027423 & 0.0642005 \\
RFA & 48 & 0.00053 & 0.26190 & 0.063350 & 0.0714395 \\
RFVHED & 48 & 0.0000 & -0.01130 & -0.000929 & 0.0020922 \\
\hline
\end{tabular}

From the table above, it can be seen and explained about the results of statistical calculations of the independent and dependent variables as follows:

a. In the Tax Avoidance (BTD) variable, the minimum data is 0.00095 and the maximum is 0.20125 with an average (mean) of 0.028817 and a standard deviation of 0.0298742 .

b. In the Free Profitability (ROE) variable the minimum data is 0.00040 and the maximum is 2.69000 with an average (mean) of 0.141304 and a standard deviation of 0.3905768 .

c. In the Foreign Activity (FA) variable, the minimum data is 0.00580 and the maximum is 0.93955 with an average (mean) of 0.314835 and a standard deviation of 0.2836875 .

d. In the Hedging variable (FVHED) the minimum data is 0.00000 and the maximum is 0.05391 with an average (mean) of 0.004563 and a standard deviation of 0.0103585 .

e. Profitability variable which is influenced by Executive Character (RROE) the minimum data is 0.00005 and the maximum is 0.41157 with an average (mean) of 0.0274 and a standard deviation of 0.06420 .

f. In the Foreign Activity variable which is influenced by the Executive Character (RFA), the minimum data is 0.00053 and the maximum is 0.26190 with an average (mean) of 0.0633 and a standard deviation of 0.07144 .

g. In the Hedging variable which is influenced by the Executive Character (RFVHED) the minimum data is 0.0000 and the maximum is -0.01130 with an average (mean) of 0.0009 and a standard deviation of 0.00209 . 
This indicates that the quality of the data from this research is quite good, because the mean value is greater than the standard deviation value which indicates that the standard error of each variable is small.

\subsection{Normality Test Results}

The normality test used in this research is the Kolmogorov Smirnov test. This normality test aims to determine whether the data in the regression model is normally distributed or not. The results of testing the normality of the data in this research can be seen in table 3 below.

Table 3. One-Sample Kolmogorov-Smirnov test

\begin{tabular}{lll}
\multicolumn{2}{c}{ Table 3. One-Sample Kolmogorov-Smirnov test } \\
\hline $\mathrm{N}$ & \multicolumn{1}{c}{ Unstandardized Residual } \\
\hline Normal Parameters ${ }^{\mathrm{a}, \mathrm{b}}$ & Mean & 48 \\
& Std. Deviation & 0 \\
Most Extreme Differences & Absolute & 0.02134711 \\
& Positive & 0.094 \\
& Negative & -0.094 \\
Test Statistic & & 0.094 \\
Asymp. Sig. (2-tailed) & $.200^{\mathrm{c}, \mathrm{d}}$ \\
a. Test distribution is Normal. & \\
b. Calculated from data. & \\
c. Lilliefors Significance Correction. & \\
d. This is a lower bound of the true significance. & \\
\hline
\end{tabular}

The Kolmogorov-Smirnov test results show a significant probability value (Asymp. Sig) of 0.20 or $20 \%$. p value or Asymp. Sig $>0.05$, it can be concluded that the residual data is normally distributed. In other words, the regression model of this research is normally distributed.

\subsection{Classic Assumption Test}

\section{a) Multicollinearity Test Results}

The multicollinearity test aims to test whether in the regression model that is formed there is a high or perfect correlation between the independent variables or not. In this research, the multicollinearity test used the TOL (Tolerance) and VIF (Variance Inflation Factor) values. Detection of multicollinearity values can be done by looking at the VIF value from the results of the regression analysis. If the VIF value is $<10$, the data in the research is free from multicollinearity symptoms. The results of the data multicollinearity test in this research can be seen in table 4 below:

Table 4. Multicollinearity Test Results

\begin{tabular}{|c|c|c|c|}
\hline \multicolumn{4}{|c|}{ Coefficients $^{\mathrm{a}}$} \\
\hline & \multirow[t]{2}{*}{ Model } & \multicolumn{2}{|c|}{ Collinearity Statistics } \\
\hline & & Tolerane & VIF \\
\hline \multirow[t]{5}{*}{1} & (Constant) & & \\
\hline & Return on Asset & 0.034 & 29.254 \\
\hline & Foreign Activity & 0.313 & 3.197 \\
\hline & Hedging & 0.171 & 5.838 \\
\hline & RROA & 0.032 & 31.465 \\
\hline
\end{tabular}




\begin{tabular}{|c|c|c|}
\hline \multicolumn{3}{|c|}{ Coefficients $^{\mathrm{a}}$} \\
\hline \multirow[t]{2}{*}{ Model } & \multicolumn{2}{|c|}{ Collinearity Statistics } \\
\hline & Tole & VIF \\
\hline RFA & 0.321 & 3.116 \\
\hline RFVHED & 0.115 & 8.719 \\
\hline
\end{tabular}

Based on the test results in table 3 , it can be seen that all VIF values of all independent variables in this research have VIF values $<10$, except for ROA and RROA but this is due to the moderating variable. This shows that the regression model is reliable and objective, so it can be concluded that the regression model is free from the symptoms of multicollinearity.

\section{b) Heteroscedasticity Test Results}

In this research, the heteroscedasticity test used the Glejser test. The results of the heteroscedasticity test of the data in this research can be seen in table 5 below:

Table 5. Heteroscedasticity Test Results

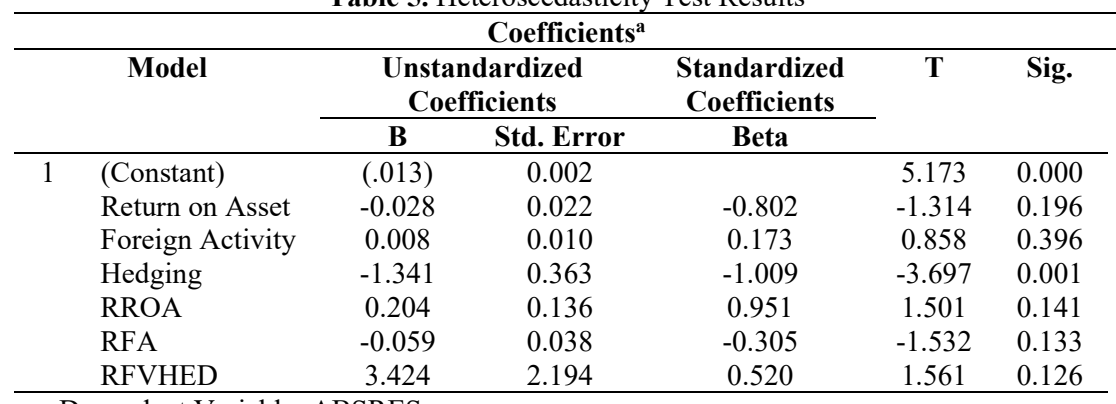

a. Dependent Variable: ABSRES

A data is said to contain heteroscedasticity if its significance value is more than 0.05 . From the results of the Glejser test, the data of this research was obtained that the average significance value of all variables was above 0.05. For the ROA, FA, RROA, RFA, and RFVHED variables, the significance value of the five variables is above 0.05 , however, for the FVHED variable, the significance value of these variables is below 0.05 . From the results of the Glejser test, it can be concluded that the residual data does not occur heteroscedasticity.

\section{c) Autocorrelation Test Results}

The autocorrelation test used in this research was the Durbin-Watson test. The autocorrelation test is used to determine whether or not there is a correlation between the residuals in an observation and other observations in the regression model. the prerequisite that must be met is the absence of autocorrelation in the regression model. Table 6 and Figure 2 presents the Autocorrelation Test Result: 
Table 6. Autocorrelation Test Results

\begin{tabular}{cccccc}
\hline Model & R & R Square & $\begin{array}{c}\text { Adjusted R } \\
\text { Square }\end{array}$ & $\begin{array}{c}\text { Std. Error of } \\
\text { the Estimate }\end{array}$ & $\begin{array}{c}\text { Durbin- } \\
\text { Watson }\end{array}$ \\
\hline 1 & $0.700^{\mathrm{a}}$ & 0.489 & 0.4157 & 0.0228558 & 2.054 \\
\hline
\end{tabular}

a. Predictors: (Constant), RFVHED, Return on Equity, Foreign Activity, RFA, Hedging, RROE

b. Dependent Variable: Book Tax Difference

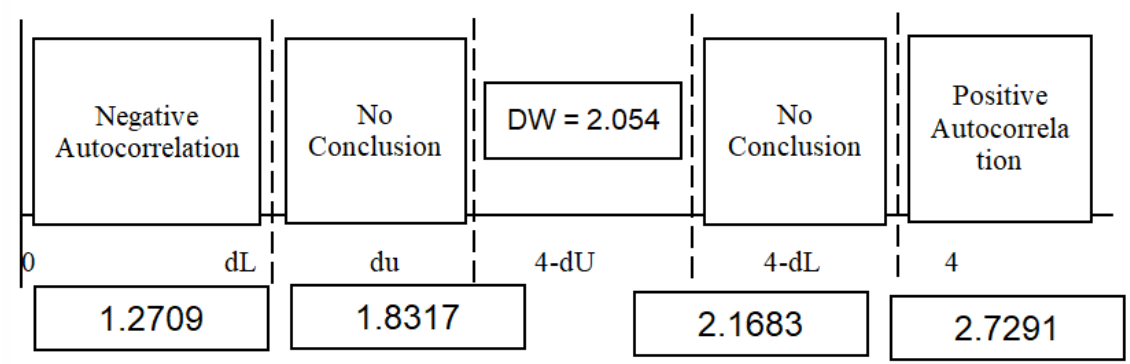

Fig. 2. Autocorrelation Test Result

The results from the table above show that the multiple regression model made has met the assumption of free autocorrelation. This can be seen from the calculated DW value of 1.829 which is in the area where there is no autocorrelation, which is in the range of DL $<$ DW $<4$ DU, namely $1.2709<1.8317<2.1683$, the value of 2.1683 is obtained from the result of subtracting 4 minus 1.8317 . So it can be concluded that there is no autocorrelation in the data.

\subsection{Hypothesis Testing}

\section{a) Coefficient of Determination Test Results}

Regression test model or coefficient of determination test between Profitability, Foreign Activity, and Hedging variables as independent variables on Tax Avoidance as the dependent variable with Executive Character as the moderating variable. Table 7 presents the result of Coefficient of Determination Test Result

Table 7. Coefficient of Determination Test Result

\begin{tabular}{cccccc}
\hline Model & R & R Square & $\begin{array}{c}\text { Adjusted R } \\
\text { Square }\end{array}$ & $\begin{array}{c}\text { Std. Error of } \\
\text { the Estimate }\end{array}$ & $\begin{array}{c}\text { Durbin- } \\
\text { Watson }\end{array}$ \\
\hline 1 & $0.700^{\mathrm{a}}$ & 0.489 & 0.415 & 0.2285584 & 2.054 \\
\hline
\end{tabular}

a. Predictors: (Constant), RFVED, Return On Equity, Foreign Activity, RFA, Hedging, RROE

b. Dependent Variable: Book Tax Difference

The table above explains that Adjusted R2 (coefficient of determination) $=0.415$ means that the variation of the independent variable is able to explain the variation of the dependent variable is $41.5 \%$. While the rest $(100 \%-41.5 \%=58.5 \%)$ is a variation of other independent variables that affect the capital structure that is not contained in this research. 


\section{b) F-Test (Simultaneous Test)}

Simultaneous F-test is a form of testing conducted to see the effect simultaneously or simultaneously between the independent variables on the dependent variable. Table 8 presents the results from the F Test or Simultaneous Test:

Table 8. F-test Result

\begin{tabular}{llccccc}
\hline & \multicolumn{7}{c}{ ANOVA $^{\mathbf{a}}$} \\
\hline & Model & Sum of Squares & df & Mean Square & F & Sig. \\
\hline 1 & Regression & 0.021 & 6 & 0.003 & 6.550 & $0.000^{\mathrm{b}}$ \\
& Residual & 0.021 & 1 & 0.001 & & \\
& Total & 0.042 & 7 & & & \\
\hline
\end{tabular}

a. Dependent Variable: Book Tax Difference

b. Predictors: (Constant), RFVHED, Return on Asset, Foreign Activity, RFA,

Hedging, RROA

Based on the table above, it is known that a significant value of 0.000 or less than the probability value ( $\mathrm{p}$-value) of $0.000(0.000<0.05)$ means that the independent variables have a significant effect simultaneously (simultaneously) on the dependent variable. In addition, the calculated $F$ value of 6.550 is greater than the F-table value of 2.29 so it can be concluded that together the independent variables have a significant effect on the dependent variable or ROE, FA, FVHED, RROE, RFA, and RFVHED have a joint effect. same for BTD.

\section{c) Partial t Test (Individual Test)}

This test is done by looking at the significance value of each relationship. The level of significance $(\alpha)$ that is set is $5 \%$, which means that the tolerable error tolerance limit is $5 \%$. In other words, the level of confidence from this proposition test is $95 \%$. If the p-value $<0.05$, it can be said that the independent variable has a significant effect on the dependent variable. Table 9 presents the result of Partial t-test

Table 9. Partial t-test Result

\begin{tabular}{|c|c|c|c|c|c|c|c|}
\hline \multicolumn{8}{|c|}{ Coefficients $^{\mathbf{a}}$} \\
\hline & \multirow[t]{2}{*}{ Model } & \multicolumn{2}{|c|}{$\begin{array}{l}\text { Unstandardized } \\
\text { Coefficients }\end{array}$} & \multirow{2}{*}{$\begin{array}{c}\begin{array}{c}\text { Standardized } \\
\text { Coefficients }\end{array} \\
\text { Beta }\end{array}$} & \multirow[t]{2}{*}{$\mathbf{t}$} & \multirow[t]{2}{*}{ Sig. } & \multirow{2}{*}{$\begin{array}{c}\text { Sig } \\
\text { One } \\
\text { Tailed }\end{array}$} \\
\hline & & B & Std. Error & & & & \\
\hline \multirow[t]{7}{*}{1} & (Constant) & 0.017 & 0.005 & & 3.279 & 0.002 & \\
\hline & Return on Asset & -0.103 & 0.046 & -1.352 & -2.240 & 0.031 & 0.050 \\
\hline & Foreign Activity & 0.060 & 0.021 & 0.570 & 2.857 & 0.007 & 0.242 \\
\hline & Hedging & -0.119 & 0.778 & -0.041 & -0.153 & 0.879 & 0.013 \\
\hline & RROA & 0.744 & 0.291 & 1.598 & 2.553 & 0.014 & 0.004 \\
\hline & RFA & -0.262 & 0.082 & -0.626 & -3.180 & 0.003 & 0.471 \\
\hline & RFVHED & 4.335 & 4.705 & 0.304 & 0.921 & 0.362 & 0.000 \\
\hline
\end{tabular}

a. Dependent Variable: Book Tax Difference

Formula (7) presents the regression equation for the hypothesis in this research:

$$
\begin{aligned}
& Y=\alpha+\beta_{1} X_{1}+\beta_{2} X_{2}+\beta_{3} X_{3}+\beta_{4} X_{1} X_{4}+\beta_{5} X_{2} X_{4}+\beta_{6} X_{3} X_{4}+€ \\
& Y=0.017+(-0.103) X_{1}+0.060 X_{2}+(-0.119) X_{3}+0.744 X_{1} X_{4}+(-0.262) X_{2} X_{4}+4.335 X_{3} X_{4}+€
\end{aligned}
$$


1. The equation above explains that the constant is 0.017 , indicating that the variables are Profitability (ROA), Foreign Activity (FA), Hedging (FVHED), Profitability moderated by Executive Character (RROA), Foreign Activity moderated by Executive Character (RFA) and Hedging which is moderated by Executive Character (RFVHED) of 0 or considered constant, then the dependent variable, namely Tax Avoidance (BTD) will increase by 0.017 .

2. Return on Assets has a coefficient of -0.103 . This shows that if the Return on Assets has increased by 1 while other variables are considered constant, then the profitability variable will decrease by 0.103 .

3. Foreign Activity has a coefficient of 0.060 . This shows that if Foreign Activity increases by 1 while other variables are considered constant, then the Foreign Activity variable will increase by 0.060 .

4. Hedging has a coefficient of -0.119 . This shows that if hedging increases by 1 while other variables are considered constant, then the hedging variable will decrease by 0.119 .

5. Return on Assets moderated by Executive Character has a coefficient of 0.744 . This shows that if the Return on Assets moderated by Executive Character has increased by 1 while other variables are considered constant, then the asset structure variable will increase to 0.744 .

6. Foreign Activity moderated by Executive Character has a coefficient of -0.262 . This shows that if Foreign Activity moderated by Executive Character increases by 1 while other variables are held constant, then Foreign Activity variable moderated by Executive Character will decrease to 0.262 .

7. Hedging moderated by Executive Character has a coefficient of 4,335. This shows that if Hedging moderated by Executive Character has increased by 1 while other variables are held constant, then Hedging variable moderated by Executive Character will increase to 4,335 .

Based on the results of the t-test above, it can be explained as follows:

H1: Profitability has a positive effect on tax avoidance

Based on the table above, it can be said that the Return on Assets variable has a significant effect on tax avoidance with a significance level of $0.050=0.05$ and an estimate value $(\beta)$ 0.103 . Therefore, it can be concluded that $\mathrm{H} 1$ is rejected, which means that profitability has a negative effect on tax avoidance.

H2: Foreign activity has a positive effect on tax avoidance

Based on the table above, it can be said that the foreign activity variable affects the firm value with a significance level of $0.242>0.05$ and an estimate value ( nilai) of 0.060 . Therefore, it can be concluded that $\mathrm{H} 2$ is accepted, which means that foreign activity has a positive and significant effect on tax avoidance.

H3: Hedging has a positive effect on tax avoidance

Based on the table above, it can be said that the hedging variable has a positive effect on tax avoidance with a significance level of $0.013<0.05$ and an estimate value $(\beta)$ of 0.119 . Therefore, it can be concluded that $\mathrm{H} 3$ is accepted, which means that hedging has a positive effect on tax avoidance.

H4: Executive characteristics moderate the effect of profitability on tax avoidance

Based on the table above, it can be said that the Return on Assets variable moderated by Executive Character has no significant effect on tax avoidance with a significance level of $0.004<0.05$ and an estimate value $(\beta)$ of 0.744 . Therefore, it can be concluded that H4 is 
rejected, which means that profitability moderated by executive character has no significant effect on tax avoidance.

H5: Executive characteristics moderate the effect of foreign activity on tax avoidance

Based on the table above, it can be said that the executive variable with the characteristics of risk taker actually weakens the positive influence of foreign activity on tax avoidance with a significance level of $0.471>0.05$ and an estimate value $(\beta)$ of -0.262 . Therefore, it can be concluded that $\mathrm{H} 5$ is rejected, which means that foreign activity moderated by executive character has no significant effect on tax avoidance.

H6: Executive characteristics do not affect hedging on tax avoidance

Based on the table above, it can be said that the Hedging variable moderated by Executive Characteristics has no significant effect on tax avoidance with a significance level of 0.000 $<0.05$ and an estimate value $(\beta)-4.335$ Therefore, it can be concluded that H6 is rejected, which means moderated hedging executive characteristics have no significant effect on tax avoidance.

\subsection{Discussion}

\section{a) The Effect of Profitability on Tax Avoidance}

Based on the results of the tests that have been carried out, it is known that the Return on Assets (ROA) variable as a profitability proxy has a significant effect on tax avoidance with a significance level of $0.050<0.005$ and an estimate value $(\beta)-0.103$. Therefore, it can be concluded that (H1) is rejected, which means that profitability has a negative effect on tax avoidance. Although the theory states that there is a positive relationship between profitability and tax avoidance, the results of the tests conducted show that companies that generate profits do not increase the company's level of tax avoidance.

These results indicate that if the company has a high ROA value, then the company can utilize assets effectively and efficiently. Companies that have a positive ROA value also feel supervised by the authorities, making it difficult to practice tax avoidance.

This research has results that are inversely proportional to the results of research conducted by Andhari \& Sukartha, which states that there is a positive relationship between profitability and tax avoidance where the larger the company generates profits, the more likely the company uses tax avoidance practices in reducing the value of its tax obligations [11]. However, research conducted by Salman \& Juniarti, shows the same results where profitability has no effect on tax avoidance [2].

\section{b) The Effect of Foreign Activity on Tax Avoidance}

Based on the results of the tests that have been carried out, it is known that the foreign activity variable affects the firm value with a significance level of $0.242<0.05$ and an estimate value $(\beta)$ of 0.060 . Therefore, it can be concluded that $(\mathrm{H} 2)$ is accepted, which means that foreign activity has a positive and significant effect on tax avoidance. This is because the company's management seeks to minimize taxes by utilizing overseas subsidiaries operating in countries with lower tax rates than Indonesia. This research has results that are in accordance with the results of research conducted Afriani et al., Ferdiawan \& Firmansyah, which state that the Foreign Activity variable has a significant effect on tax practices [5], [6]. avoidance. However, the results of research conducted by Sari \& Ajengtiyas, show contradictory results, namely that there is no influence of foreign activity variables on tax avoidance [23]. 


\section{c) The Effect of Hedging on Tax Avoidance}

Based on the results of the research that has been done, it is known that the hedging variable affects the value of the company with a significance of $0.013>0.05$ and an estimate value of $(\beta)$ 0.119. Therefore, it can be concluded that $\mathrm{H} 3$ is accepted, which means that hedging has a positive effect on tax avoidance. This can happen because companies that hedge get tax benefits by reducing the volatility of taxable income so as to reduce the tax burden. Oktavia \& Martani, proves that users of derivatives such as hedging have a higher level of aggressiveness than non-users of derivatives [19]. The same result was also stated by Lee (2016) in his research that hedging has a significant positive effect on tax aggressiveness, where tax avoidance is one of the ways companies carry out tax aggressiveness.

\section{d) The Effect of Profitability on Tax Avoidance Moderated by Executive Character Variables}

Based on the results of the tests that have been carried out, it is known that the Executive Character which moderates the Return On Asset variable weakens the negative influence of firm value with a significance level of $0.004<0.05$ and an estimate value $(\beta)$ of 0.744 . Therefore, it can be concluded that (H4) is accepted, which means that the Executive Character moderates the negative effect of Profitability on tax avoidance. This can happen because executives who have a risk taker character tend to have the potential to do tax avoidance as stated in research Maharani \& Suardana, although the company's ROA tends to be high, but with the character of executives who dare to take risks, this may not necessarily be successful [20]. make the Executive consider and cancel his decision in tax avoidance.

\section{e) The Effect of Foreign Activity on Tax Avoidance Moderated by Executive Character Variables}

Based on the test results, it can be concluded that the Executive Character which moderates the Foreign Activity variable weakens the positive influence of firm value with a significance level of $-0.262<0.05$ and an estimate value $(\beta)$ of 0.471 . Therefore, it can be concluded that (H5) is accepted, which means that the Executive Character moderates the positive influence of Foreign Activity on tax avoidance. This means that executives who have the characteristics of risk takers or tend to be brave in making decisions do not always make a company that has foreign operations carry out tax avoidance or tax avoidance by taking advantage of lower tax rates in multinational companies because in general these companies tend to be supervised by more than one country due to their foreign activities and are very careful in taking business steps including tax avoidance

\section{f) The Effect of Hedging on Tax Avoidance Moderated by Executive Character Variables}

Based on the results of the tests that have been carried out, it is known that the Executive Character moderating the Hedging variable does not affect the relationship between Hedging and tax avoidance with a significance level of $0.000<0.05$ and an estimate value $(\beta)$ of 4.335 . Therefore, it can be concluded that (H6) is rejected, which means that the Executive Character does not moderate the positive effect of hedging on tax avoidance. Hedging usually will do tax avoidance by taking advantage of the company's low risk in disclosing information to 
stakeholders. With the test results listed in this research, executives with risk taker characters have no relationship with companies that do tax avoidance by utilizing hedging.

\section{Conclusion}

Based on the results of the analysis that has been carried out in the previous chapter, it can be concluded as follows:

a. The results of the partial test prove that the Profitability (ROA) variable has a negative and significant effect on the tax avoidance of multinational companies listed on the IDX in 2017-2019.

b. The results of the partial test prove that the Foreign Activity (FA) variable has a positive and significant effect on the tax avoidance of manufacturing multinational companies listed on the Indonesia Stock Exchange in 2017-2019.

c. The results of the partial test prove that the Hedging variable (FVHED) has a positive effect on the tax avoidance of multinational companies listed on the IDX in 2017-2019.

d. The results of the partial test prove that the variable Executive Character (RISK) which moderates Return on Assets weakens the negative effect of Profitability on the tax avoidance of multinational companies listed on the IDX in 2017-2019.

e. The results of the partial test prove that the Executive Character which moderates the Foreign Activity variable weakens the positive influence of Foreign Activity on the tax avoidance of multinational companies listed on the IDX in 2017-2019.

f. The results of the partial test prove that the Executive Character which moderates the Hedging variable has no effect on multinational tax avoidance listed on the IDX in 20172019.

\section{Limitations}

a. This research has several limitations which, if overcome by further research, will be able to improve the results of this research, namely:

b. This research has a limited time period, namely for 3 years between 2017-2019, so the research results obtained only describe short-term conditions.

c. The results of the heteroscedasticity test using the Glejser test for hedging variables have limitations, namely the significance value is less than 0.05 .

d. The results of the Multicollinearity test in table 3 for the ROA and RROA variables have limitations, namely the VIF value is more than 10 due to the moderating variable.

e. This research has a limited sample because of the hedging variable that must exist in a company.

\section{Suggestion}

Based on this research, the authors provide suggestions are as follows:

a. For Owners and Management

Company management is required to minimize this tax avoidance practice. Tax avoidance is one way to avoid taxes without violating the rules of taxation. Although no law was violated, all parties agreed that tax evasion was unacceptable. This is because tax avoidance directly results in reduced state revenues.

b. For Investors

1. Investors are advised to pay attention to investment based on considerations of 
executive character, profitability, foreign activity, and hedging in an effort to minimize tax avoidance by companies.

2. Investors are advised to pay attention to investment risk in investing based on the considerations of the executive character, profitability, foreign activity, and hedging.

c. For further researchers

1. Further research can conduct a more in-depth research of Tax Avoidance by adding other variables.

2. Future researchers are expected to add and expand the period and object of research so that they can obtain maximum results related to Tax Avoidance.

3. Future research is expected to use different measures in measuring the variables of Profitability, Foreign Activity, Hedging, Executive Character, and Tax Avoidance.

4. Future research is expected to add other variables that may affect Tax Avoidance and develop moderating variables other than the Executive Character.

\section{References}

[1] C. A. Pohan, Manajemen Perpajakan: Strategi Perencanaan Pajak dan Bisnis. Jakarta: Gramedia Pustaka Utama, 2013.

[2] A. Salman dan J. Juniarti, "Pengaruh Akuntabilitas Keuangan, Transparansi, Pengawasan, dan Penyajian Laporan Keuangan Terhadap Pengelolaan Keuangan Daerah Pada Pemerintah Kota Bekasi (Periode Tahun 2015 - 2018)," S1 Akunt., hal. 114, 2021.

[3] M. Z. Zamani, "Pengaruh Financial Distress, Sales Growth, dan Foreign Activity Terhadap Tax Avoidance (Studi Empiris pada Perusahaan yang Terdaftar di Indeks Saham Syariah Indonesia Tahun 2017-2018)," Universitas Muhammadiyah Malang, 2020.

[4] N. N. K. Dewi dan I. K. Jati, "Pengaruh karakter eksekutif, karakteristik perusahaan, dan dimensi tata kelola perusahaan yang baik pada tax avoidance di bursa efek Indonesia," E-Jurnal Akunt. Univ. Udayana, vol. 6, no. 2, hal. 249-260, 2014.

[5] F. Afriani, E. Safitri, dan R. Aprilia, "Pengaruh likuiditas, leverage, profitabilitas, ukuran perusahaan dan growth terhadap kebijakan dividen.” STIE MDP, 2015.

[6] Y. Ferdiawan dan A. Firmansyah, "Pengaruh political connection, foreign activity, dan, real earnings management terhadap tax avoidance," J. Ris. Akunt. Dan Keuang., vol. 5, no. 3, hal. 1601-1624, 2017.

[7] R. Andikasari dan Sugiyono, "Pengaruh Return On Equity, Price Earning Ratio, Earning Per Share dan Firm Size terhadap Harga Saham," J. Ilmu dan Ris. Manaj., vol. 7, no. 2, 2018

[8] J. Madura, "Manajemen keuangan internasional," Alih Bhs. Emil Salim, 2000.

[9] K. Lewellen, "Financing decisions when managers are risk averse," J. financ. econ., vol. 82, no. 3, hal. 551-589, 2006.

[10] A. Sartono, Manajemen Keuangan Teori dan Aplikasi. Yogyakarta: BPFE Yogyakarta, 2010.

[11] P. A. . Andhari dan I. . Sukartha, "Pengaruh Pengungkapan Corporate Social Responsibility, Profitabilitas, Inventory Intensity, Capital Intensity dan Leverage pada Agresivitas Pajak," E-Jurnal Akunt. Univ. Udayana, vol. 18, no. 3, hal. 2115-2142, 2017.

[12] S. O. Rego, "Tax-avoidance activities of US multinational corporations," Contemp. 
Account. Res., vol. 20, no. 4, hal. 805-833, 2003.

[13] K. . Subramanyam dan Wild, Analisis Laporan Keuangan, 10 ed. Jakarta: Penerbit Salemba Empat, 2010.

[14] A. Low, "Managerial risk-taking behavior and equity-based compensation," J. financ. econ., vol. 92, no. 3, hal. 470-490, 2009.

[15] R. Palan, Tax havens and the commercialization of state sovereignty. New York: Cornell University Press, 2008.

[16] D. A. Guenther, "Measuring corporate tax avoidance: Effective tax rates and book-tax differences," Available SSRN 2478952, 2014.

[17] S. Aisyah dan H. Setiyawati, "The Effect of Executive Character and Implementation of Good Corporate Governance to Tax Avoidance ( Empirical Study on Companies Moving Consumer Goods Sector Industry Listed in Indonesian Stock Exchange in 2013-2017)," Sch. Bull. Sch. Middle East Publ. Dubai, United Arab Emirates, vol. 5, no. 7, hal. 399-405, 2019, doi: 10.21276/sb.2019.5.7.13.

[18] M. P. Donohoe dan W. Robert Knechel, "Does corporate tax aggressiveness influence audit pricing?," Contemp. Account. Res., vol. 31, no. 1, hal. 284-308, 2014.

[19] Oktavia dan D. Martani, "Tingkat pengungkapan dan penggunaan derivatif keuangan dalam aktivitas penghindaran pajak," J. Akunt. dan Keuang. Indones., vol. 10, no. 2, hal. 129-146, 2013.

[20] I. G. A. C. Maharani dan K. A. Suardana, "Pengaruh corporate governance, profitabilitas dan karakteristik eksekutif pada tax avoidance perusahaan manufaktur," E-Jurnal Akunt. Univ. Udayana, vol. 9, no. 2, hal. 525-539, 2014.

[21] W. S. Ramadhani, D. N. Triyanto, dan K. Kurnia, "Pengaruh Hedging, Financial Lease dan Sales Growth terhadap Agresivitas Pajak," J. Appl. Account. Tax., vol. 5, no. 1, hal. 107-116, 2020.

[22] Sugiyono, Metode Penelitian Kuantitatif, Kualitatif dan R\&D. Bandung: Alfabeta, 2009.

[23] R. H. D. P. Sari dan A. Ajengtiyas, "Pengaruh Profitabilitas, Transfer Pricing, dan Manajemen Laba Terhadap Tax Avoidance," Konf. Ris. Nas. Ekon. Manaj. dan Akunt., vol. 2, no. 1, hal. 898-917, 2021. 
